\title{
ADOPTION OF COMPETITOR FOCUSED ACCOUNTING METHODS IN SELECTED MANUFACTURING COMPANIES IN NIGERIA
}

\author{
Chiekezie, Njideka \\ Rita $^{1}$ \\ Egbunike, Patrick \\ Amaechi $^{2+}$ \\ Odum, Austin \\ Nwekemezie $^{3}$
}

\author{
'Department of Accountancy, St. Paul's University College, Awka, Anambra State, \\ Nigeria \\ ${ }^{2,3}$ Department of Accountancy, Nnamdi Azikiwe University, Awka, Anambra State \\ Nigeria \\ (+ Corresponding author)
}

\section{Keywords}

Adoption

Competitor

Focused accounting

Methods

Nigeria.

\section{ABSTRACT}

This study-examined the extent of adoption of competitor focused accounting (CFA) in selected manufacturing firms listed on Nigerian Stock Exchange with a view to establishing whether there are differences in financial performance of the firms. The study is descriptive in nature and uses survey techniques. Accordingly, twohundred and twenty four (224) key respondents in the Nigerian manufacturing industry were surveyed. This is complimented with secondary data collected from annual accounts and reports of fifty six (56) manufacturing companies listed in the Nigerian stock exchange. In addition to descriptive statistics, analysis of variance ( $\mathrm{F}$ - Ratio) and scheffes' (fs) test were used in analyzing collected data. The result of the study revealed that 14 companies representing (25\%) were nonadopters of competitor focused accounting methods, 36 (64.3\%) were partial adopters while $6(10.7 \%)$ were full adopters. In addition, the mean financial performance of full adopters of CFA methods was 25.1 greater than that of partial adopters and also 45.71 greater than nonadopters. This shows a large difference. On the other hand, partial adopters' mean financial performance was 20.61 greater than that of non adopters of CFA methods. However, this study proves that the practice of CFA in Nigerian manufacturing companies is still below average and the necessity to improve this situation is the current challenge. Manufacturing firms in Nigeria should give priority to strategic management accounting and it sub-divisions especially CFA in other to enhance its competitive edge over competitors.

Contribution/ Originality: This study is one of very few studies that have investigated Competitor Focused accounting CFA in the manufacturing subsector of the Nigerian economy. The study classified the firms in adopters, partial-adopters and non-adopters of CFA; and used 
scheffes pair-wise comparison test to establish the differences in performance among the three groups with respect to $\mathrm{CFA}$ adoption. By using scheffes test, the study employed new methodology in estimating adoption of CFA and using this to establish differences in financial between the groups of manufacturers with respect to adoption of CFA. The new methodology and estimation also stem from the fact that the group of the firms were based on the responses of the managers/Chief Executive and not just reported information.

\section{INTRODUCTION}

Today's business environment is changing faster than ever before and the companies' success in the market depends on the timely possession of quality information. (Malinic et al., 2012). Competitor focused accounting (CFA) practice in organizations is particularly important in creating a strong information base for making the right strategic decision and achieving performance. To make good strategic decisions, and thus achieve competitive advantage, firms must obtain information about important competitors and using that information to predict competitor behaviour and improve their own operations. Without information on current and potential competitors, the contemporary company does not have many opportunities for survival and development. To meet the challenges of the environment and make good strategic decisions, a company must know its competitors and market situation, that is, must understand the importance of the information provided by the CFA system.

Competitor- Focused Accounting (CFA) opens up new vistas for management accounting by contributing to making strategic decisions in the company as well as more effective control of their operations. CFA positions the company to a place which has the best view of the existing and potential competitor activity all with the aim of creating added value and improving the company operations. According to Malinic et al. (2012), CFA is the extended arm of strategic management accounting, aimed at creating a strong information base upon which contemporary companies should build their competitive advantage. Simmonds (1986) also affirms that CFA helps the firm evaluate its competitive position relative to the rest of the industry by collecting data on costs and prices, sale volume, and market share. To protect an organization's strategic position and determine strategies to improve its future competitiveness, management require information that indicates by whom, how and why they are gaining competitive edge or are being taken advantage of. This information signals the need for a change in competitive strategy for sustainable advantage. CFA is fundamental to the pursuit of competitive advantage and competitive advantage is at the heart of a firm's performance. Thus, when a firm earns superior financial returns within its industry, over a long run, it experiences competitive advantage over its rivals. CFA provides relevant and accurate information for this purpose; this means that if information about the competitors is not available, then, taking advantage of them becomes a mere illusion (Akenbor, 2011). This demonstrates the essence of competitor accounting and analysis, and therefore, requires a considerable attention.

In respect of manufacturing industry, the nature of operations and competition requires that companies should continuously use elements of competitor information, which could foster continuous cost reduction and product innovations. Manufacturing firms play an important role 
in fostering growth as evidenced in developed and few emerging economies; however, the performance and productivity of Nigeria's manufacturing firms have deteriorated at present. This implies that there are not growth propelling resources at the disposal of manufacturing firms in Nigeria over the years as such their growth mechanisms tend to deteriorate (Sangosanya, 2011). It is imperative, therefore, for manufacturing firms to consider adopting cost management and strategic initiatives in order to gain competitive advantage, which increases the chance for firms' financial performance. Thus, the study investigates the extent of adoption of CFA methods with a view to determining whether there is any significant difference in financial performance of the manufacturing firms. Predicated on this argument, the paper formulated here under mentioned hypothesis:

\section{Ho: Full adopters, partial adopters and non-adopters of CFA methods do not differ significantly in financial performance.}

The rest of the paper is organized in the following manner: Introduction is in section one, section two provides Theoretical framework, section three covers Review of Related Literature, section four covers methodology while section five deals Results and Disscusion and section six cover conclusion and recommendation

\section{THEORETICAL FRAMEWORK}

In developing a theoretical foundation to study the relationship between CFA and financial performance, the researcher draws on Agency Theory, Profit Maximizing or Competition based Theory and Rogers's Theory of Perceived Attribute. In management accounting research, agency theory focuses on the relationship between principals (shareholders of afirm) and agents (managers). The principals contract with the agents to perform someservices on the principal's behalf.The principals and agents both seek to maximize their utility from the same organizations. Today, company shareholders normally contract managers to run their businesses and the strategic decisions are undertaken by these managers. The decisions are undertaken by the organization's management (agents) on behalf of the company owners (principals) under the power entrusted to them through their employment contracts.For the managers to make good strategic decisions, attain and sustain competitive advantage, the wealth of information on relevant factors that emanate from the environment is relevant, hence, CFA practice .

In the accounting literature, profit maximization theory is based on the notion that business organizations' main objective is to maximize long-term profit while developing sustainable competitive advantage over competitive rivals in the external market place. The basic premise of this theory in the field of strategic management is; the strategies will be driven primarily (but not exclusively) by the objective of maximizing the organizations' profitability in the long run with the ultimate purpose of developing sustainable competitive advantage over the competitor (Lynch, 2000). The application of this theory to the field of strategic management is straight forward. The objective of every organization is to enhance the company's profit. This means that profit-maximization is the main objective available for companies in order to survive. CFA is the 
extended arm of SMA, aimed at creating a strong information base upon which contemporary companies should build their competitive advantage (Malinic et al., 2012)

Drawing from Roger's theory of diffusion and perceived attributes, individuals will adopt an innovation if they perceive that the innovation has the following attributes. First, the innovation must have some relative advantage over an existing innovation or the status quo. Second, it is important the innovation be compatible with existing values and practices. Third, the innovation cannot be too complex. Fourth, the innovation must have trialability. This means the innovation can be tested for a limited time without adoption. Fifth, the innovation must offer observable results (Rogers, 1995). It is agreed that the adoption of CFA is influenced by the firm's perception of the usefulness of the innovation, such that those who perceive it as being highly useful would adopt it fully while those who view it as less useful would either not adopt it or partially adopt it. Consequently, those who adopt it fully would record higher performance while those who do not adopt it or adopts it partially would record lower or moderate performance respectively. It is, therefore, argued that a firm's adoption of CFA methods influences the firm's performance. Performance is used in this study as a measure of the extent of the success of the adoption or application of CFA methods.

\subsection{Review of Related Literature}

\subsubsection{Methods of Competitor Focused Accounting (CFA)}

The use of competitor focused accounting is supposed to, provide detailed insight into a competitor's present cost and financial situation; determine one's own competitive position and predict future competitive strategic behaviours Heinen and Hoffjan (2005). Akenbor and Okoye (2011) describe competitor accounting as "know your enemy accounting.

According to Guilding et al. (2000) and Milićević, (2003) as cited in Malinic et al. (2012), there are three methods of competitor focused accounting. These include:

(a) Competitor Position Monitoring (CPM): In the words of Drury (2008) CPM is defined as the analysis of competitors' positions within the industry by assessing and monitoring trends in competitors' sales, market share, volume, unit costs and return on sales . According to the information provided, the company is able to assess its own position relative to main competitors and consequently, control or formulate its strategy. CPM has proved to be the most useful tool of CFA (Malinic et al., 2012) and that information on competitors' position affect the performance of companies and that such information is especially important for productivity (Hassan et al., 2011). CPM, as advocated by Simmonds (1986) represents a more holistic mode of CFA than competitor cost assessment. It involves two main methods of supervision (Simmonds, 1986). First, the competitive position of Graph, mapped using the method map relative to the market leader in business and other major competitors in the current and future competitor's position. Indicators are some of the key variables such as unit costs, prices profitability, sales revenue, sales volumes, market share and relative market share, cash flow, cash flow rates, future needs e.t.c. This method provides different competitors with information in each competitive force in different periods of up and down panorama. 
Grundy (1997), proposed strategic health indicator method . It involves First, companies and competitors assessing the current strategic position, the current strategic position of the hardware (including product, quality, customer base, marketing channels, capacity, cost structure etc.) and competitive soft ware (including trademarks, reputation, skill, risk aversion, the level of leadership, team spirit, e.t.c). The results of the first two steps combined together gives strategies for business and competitor's health plan.

(b) Competitor cost assessment (CCA): is defined in this study as the provision of regularly updated estimate of competitors' cost structures. The advocates of this practice include Bromwish (1990), Jones (1988), Porter (1980) and Simmonds (1986). There can be different sources of such information. Ward (1996) suggests some indirect sources such as physical observation, common suppliers or customers and ex-employees of competitors. The significant attention commanded by competitor cost assessment may result partially from the growing sophistication in technologically-advanced instrument (Guilding, 1999). Jones (1988), is of the opinion that commitment associated with such investment and the implied pursuit of improved competitive position heightens the need for awareness of competitors' cost. He outlines a systemic approach to CCA that involves, inter alia, appraising competitors' manufacturing activities, economies of scale, governmental relationships, and technology-product design. Heinen and Hoffjan (2005) asserts that, the comparison of one's own cost structures with those of the competitors requires a systematic procedure that includes appraising competitors' manufacturing activities, and technology-product design an assessment of the production equipment, the economies of scale, the relationship with the cost-influencing stakeholders such as suppliers and the technological product design. In order to provide a meaningful comparative analysis of the cost data of competitors, a number of transitive calculations must be carried out. First of all, the estimation of the competitors' costs must be adjusted to the internal production volumes and the company's own product variety (Jones, 1988). The effects of future cost reduction programs by the competitors must be predicted and taken into account for the calculation of the product cost difference. Furthermore, freight costs, customs and other indirect product-related costs must be recorded and compared. Finally, an adjustment for possible differences in value between the products to be compared must be carried out. If applicable, expected exchange rate variations must also be taken into account (Heinen and Hoffjan, 2005).

A relevant source of competitor evaluation is constituted by public financial statements. Moon and Bates (1993) underline the strategic insights that it is possible to obtain from this type of analysis. The technique, which represents an elaboration of common and traditional methods, finds a strengthening in today's evolution of IASB that may allow for a simpler comparison between companies of different countries.

(c) Competitor Financial Statement Performance Appraisal (CPA): is described by Guilding (1999), as the numerical analysis of a competitor s published statements as part of an assessment of a competitor's key sources of competitive advantage. Hesford (2008) in his study, revealed that monitoring the competitors' financial statement has a positive effect 
on return on investment, economic value-added, innovation, market share, service quality, efficiency and customer satisfaction. A competitor financial statement may serve two purposes; it may be used to validate competitor cost estimates and to evaluate a competitor's overall position and strength (Hesford, 2008). One of the most important tools for assessing the strength of competitors in an industry is to analyze their financial performance.

\subsubsection{Competitor Focused Accounting and Financial Performance}

Previous researches had proven that competitor information usage improves performance. Subramanian and IsHak (1998) claim that firms which have advanced systems to monitor their competitors' activities exhibited greater profitability than firms that did not have such systems. This implies that competitive position monitoring provide detailed insight into a competitive position and predict future competitive strategic behaviour. This will enable the firm to plan effective competitive strategies for competitive advantage. The strategic management accounting literature suggests that a link exists between competitor accounting and a firm's market share (Akenbor, 2011). The extreme importance of information on competition in the contemporary process of strategic decision making in the world is evident, no matter what stage of strategic decision-making process is at issue. Knowing this information is a reliable indicator and certain path to achieving superior performances.

The result of Heinen and Hoffjan (2005) study, demonstrate that competitor cost assessment is a powerful tool for maintaining or gaining competitive advantage. According to them, knowledge of the cost advantage and disadvantage of competitors allows an anticipate of their future behaviour. In addition, the analysis of external cost information can have far-reaching implications within a company. It can influence the investment behaviour, production quantity and pricing policy. Hesford (2008), in his study asserted that the increased use of accounting information has a positive influence on the effectiveness of competitive intelligence and increased effectiveness of competitive intelligence has positive effect on corporate performance. Johnson (2002) concludes that information gained from the annual financial statement could influence strategic decisions taken by competitor thereby leading to competitive advantage. In the same vein, Gruetter-Settele (1999) cited in Heinen and Hoffjan (2005) confirms that competitors' annual financial statement analyses influence a company's competitive advantage. This is because through the analysis, competitors' 'weaknesses are revealed, which thereby serves as opportunities to the firm. (Akenbor and Okoye, 2011)found that competitor accounting has positive influence on profitability of manufacturing firms.

According to Richard et al. (2009), organizational performance encompasses three specific areas of firm outcome: First, product market performance (sales, market share e.t.c.); second, shareholder return (total shareholder return, economic value added e.t.c.) and third, financial performance (profit margin, return on equity, return on assets, return on sales). Financial performance is the concern for this study. Financial performance refers to a firm's ability to generate new resources from day to day operations over a given period. It can be considered as an index for firm's health in a specific period of time; it can be also utilized to evaluate the firm in 
an industry or compare it with other industries and economic sections (Marian, 2011). The major means of appraising the financial performance of a firm is through the profitability ratios (Akenbor, 2011). Profitability ratios are accounting ratios used to measure the overall profit performance of a firm, as revealed by the returns or earnings generated by sales and investments (Osisioma, 1996). Profits, according to Nzewi (2009), is the ultimate output of a business firm and any firm that fails to make sufficient profit has no future. Return on assets is a profitability ratio which indicates the amount of management efficiency in applying the existing resources in order to increase the profitability. It is also beneficial in analyzing the profitable resources (Marian, 2011). The rationale for using Return on Assets (ROA) is because according to Gan and Selah (2008), return on assets indicate the use efficiency of the assets while Return on sales is useful in assessing performance of the firm in term of its ability to generate profit from sales Nzewi (2009).

\section{METHODOLOGY}

The population of this study comprises 56 manufacturing firms listed on the Nigerian Stock Exchange and published in the Nigerian Stock Exchange FactBook of 2011/2012. The companies are shown in table one below.

Table-1. Population of the study showing the number of companies in each sector as published in Nigeria stock exchange factbook.

\begin{tabular}{l|l}
\hline Building Materials & 13 \\
\hline Food Products & 12 \\
\hline Health care product & 8 \\
\hline Beverage/Brewers/Distillers & 8 \\
\hline Household/Personal product & 6 \\
\hline Agric/Agro Allied & 5 \\
\hline Conglomerates & 4 \\
\hline Total & 56 \\
\hline
\end{tabular}

Data for this study were collected from both primary and secondary sources. The major primary instrument used for data collection in this study is a researcher-developed questionnaire. The population elements of this study are four (4) top/strategic management staff (Chief executive officer, Chief accountant/ Chief Financial officer, Marketing director, Chief controller or Chief planner/analyst as may be found in different companies) of the representative companies. This is because they are concerned with the responsibility of preparing reports for strategic decision-making. The secondary source of data for this study is the annual reports of various companies under study and the (Nigerians Stock Exchange Factbook, 2011/12). The financial statements in the annual reports give information on profit before tax and total assets, among others. These values were extracted and used to compute return on asset for each of the sampled company as a means of measuring the financial performance.Data obtained in this study were analysed using Analysis of Variance(F-ratio) and Scheffe's (Fs) test. Analysis of Variance (Fratio) was used to determine whether full adopters, partial adopters and non-adopters differ significantly in their financial performance. To know which particular group creates the difference or is worst hit or is superior, a multiple- group comparison test such as Scheffe's(Fs) test is used. 
F- ratio indicates whether a significant difference exists between groups while Fs provides information with respect to effectiveness or ineffectiveness of each group in the phenomenon being investigated. (Uzoagulu, 1998).

\subsection{Measurement of Variables in the Study}

The study has two main variables. The independent variable is the Competitor Focused Accounting (CFA) methods and the dependent variable is Financial Performance. The current research has conceptualized CFA information in three dimensions (methods). They include; the Competitor Cost Assessment (CCA), the Competitor Position Monitoring (CPM), and Competitor Financial Statement Performance Appraisal (CPA). A 21- item activities involved in CFA application was developed in line with Malinic et al. (2012), Cadez and Guilding (2008), Drury (2008), Heinen and Hoffjan (2005), Guilding (1999) and Moon and Bates (1993) principles of CFA methods. This consists of 9 items which measured CCA analysis, 7 items measuring CPM and another 6 items measuring CPA Analysis.

The response categories were as follows: Not at All $=1$,Little Extent $=2$, An Extent $=3$, Large Extent $=4$, Very Large Extent $=5$. To get each respondent's score (example on usage of Competitor Cost Assessment method) his/her ratings of the items on the questionnaire were summated (that is, added up). The unit of analysis was company and not individuals.

Therefore, information collected from four top members of each company was aggregated to become company level data. Such that each company had a single score for each of our explanatory (independent) variable. To achieve this, the mean values for CFA methods (CCA, CPM \& CPA) for the four respondents from each of the companies was computed and used to build up the company level data such that the original individual level data which consisted of 224 respondents (4 x 56) became a company level data consisting of 56 companies

\section{Decision Rule}

The decision rule on the extent of adoption of CFA methods was based on the scale mean. The weightings average was obtained as follows $1+2+3+4+5=15 / 5=3$. Mean score below the scale mean was interpreted as little extent while mean responses above the mean was interpreted as large extent.

\section{DATA ANALYSIS}

\subsection{Determination of Adoption of Each Method of CFA}

To determine which companies are non adopters, partial adopters and full adopters, using the response categories the schema shown below was used.

Table-2. Determination of Adopters of CFA methods.

\begin{tabular}{|c|c|c|c|c|}
\hline 1 & 2 & 3 & 4 & $\mathbf{5}$ \\
\hline Not at all & Little extent & An extent & Large extent & Very large extent \\
\hline $\begin{array}{l}\text { NON } \\
\text { ADOPTERS }\end{array}$ & PARTIAL ADOPTERS & \multicolumn{3}{|c|}{ FULL ADOPTERS } \\
\hline $1.00-1.99$ & $2.00-2.99$ & \multicolumn{3}{|c|}{$3.00-5.00$} \\
\hline
\end{tabular}


- Companies with mean score that falls within $\mathbf{1 . 0 0} \mathbf{- 1 . 9 9}$ interval was classified as non adoption of that method.

- Companies whose mean scores fell within $\mathbf{2 . 0 0} \mathbf{- 2 . 9 9}$ interval was categorized under partial adoption.

- Companies with mean scores that fell within $\mathbf{3 . 0 0} \mathbf{- 5 . 0 0}$ interval were classified as full adoption.

\subsection{Determination of Adoption of all CFA Methods Put Together}

Using the categorization of adoption of each CFA method, companies' adoption of all CFA methods was done as follows:

$\left.\begin{array}{l}\text { Non-adoption }+ \text { Non-adoption }+ \text { Non-adoption }=\text { Non adopter } \\ \text { Non-adoption }+ \text { Non-adoption }+ \text { Partial adoption }=\text { Non adopte }\end{array}\right\}$ Non Adopters $=1$

Non-adoption + Partial Adoption + full adoption $=$ Partial adopter

Partial adoption + Full Adoption + Full Adoption $=$ Partial Adopter

Partial Adopters $=2$

Partial adoption + Partial Adoption + Partial Adoption $=$ Partial Adopter

Full adoption + Full Adoption + Full Adoption $=$ Full Adopter $\}$ Full Adopters = 3

With this categorization, the frequencies and percentages were computed to determine the proportion of companies that fell within each category

\subsection{Financial Performance Measurement}

Financial performance is measured using return on assets (ROA) which is an accounting based measure of returns. The financial statement for each company for the last three years were obtained and subjected for the analysis. Thus, for each company, a 3-year average ROA was computed. This is because the study examined the usage of CFA methods for the last three years. Three years were considered so that usage in the last three years can be matched with three years financial performance.

\subsection{Result and Discussion}

An attempt to ascertain the extent of the adoption of CFA methods in manufacturing companies in Nigeria was made. The result of the study indicated that CCA in a scale ranging from 9 to 45 and a scale average of 27 , the companies' mean rating of their application was 17.42 . This indicates that the application of CCA in manufacturing organizations was far below average. The researcher, therefore, is of the opinion that the low usage rate of CCA method may be because of the difficulty associated in obtaining and analyzing information regarding the cost structures of the competitors. 
Companies mean rating of their application of CPA was 16.38 compared to 18.00 mean value in a scale ranging from 6 to 30. This suggest that application of CPA in organizations was a little below average unlike CCA which was far below average. In the same vein, companies mean rating of their application of CPM was 22.50 compared to 21.00 mean value in a scale ranging from 7 to 35. This suggests that application of CPM in organizations was above average. It is noted in this study that CPM proved to be the CFA method with the highest usage rate while CCA has the least usage rate. This is also in line with a study conducted in New Zealand by Guilding (1999), which noted that CPM is the most widely used method of CFA and is also perceived to be of the greatest help.

Table-3.Status of Adoption of Competitor Focused Accounting Methods and Mean Financial Performance in Manufacturing Companies

\begin{tabular}{l|l|l|c|c}
\hline & Frequency & Percent & Mean Difference & Std. Deviation \\
\hline Non Adopters & 14 & 25.0 & -3.19 & 10.12 \\
\cline { 1 - 2 } Partial Adopters & 36 & 64.3 & 17.42 & 10.42 \\
\cline { 1 - 2 } Full Adopters & 6 & 10.7 & 42.52 & 18.95 \\
\hline Total & 56 & 100.0 & 14.59 & 17.38 \\
\hline
\end{tabular}

Field Survey,2013

The status of adoption of CFA was ascertained using the categorizing schema stated in the methodology. As shown in table 3 above, 14 companies representing (25\%) were non-adopters of competitor focused accounting methods, 36 (64.3\%) were partial adopters while $6(10.7 \%)$ were full adopters. This is depicted in the graph presented in figure 1 below

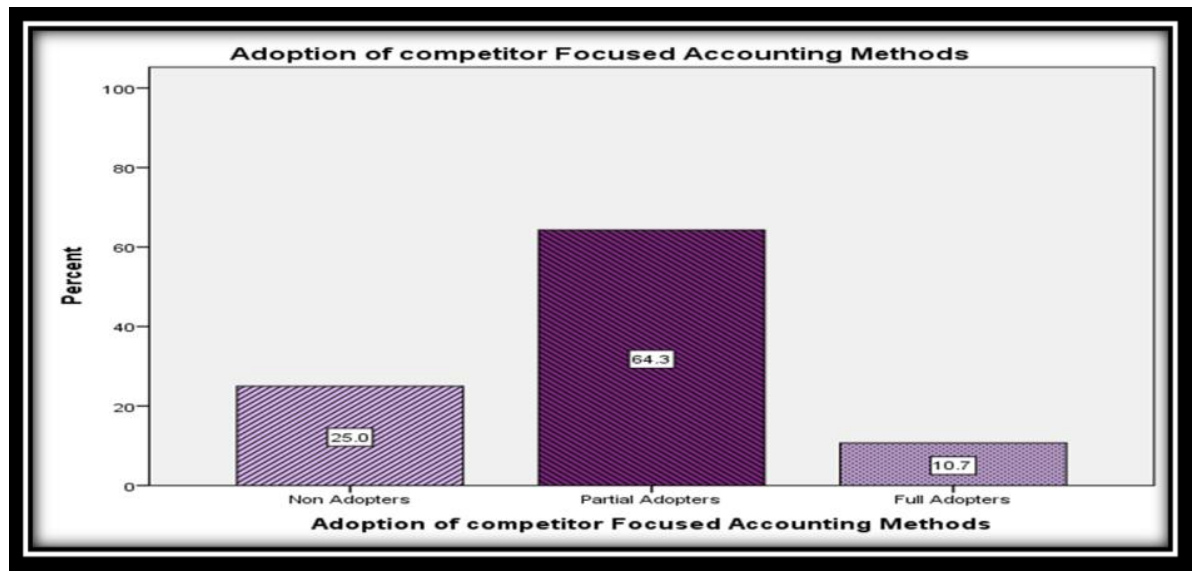

Fig-1. Bar charts showing adoption of CFA Methods by Manufacturing Companies

A look at table 3 above shows that, the mean financial performance of full adopters of CFA methods was 25.1 greater than that of partial adopters and also 45.71 greater than non-adopters. This shows a large difference. On the other hand, partial adopters' mean financial performance was 20.61 greater than that of non adopters of CFA methods. Mean plot shown below demonstrates this mean difference pictorially. 


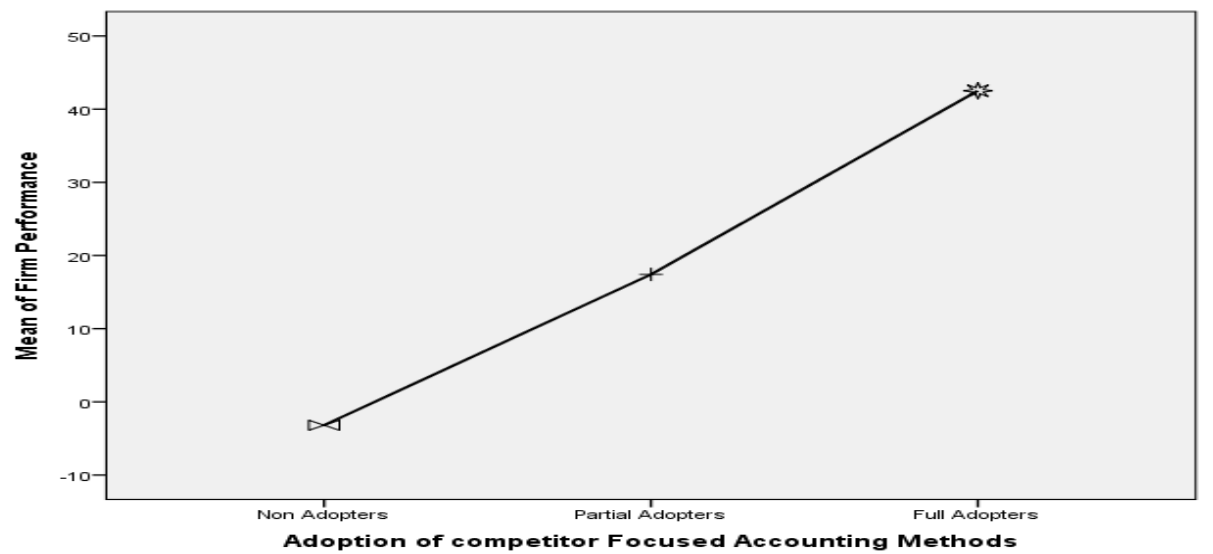

Fig-2.Mean Plot of Financial Performance of non adopters, partial adopters and full adopters of CFA methods

Table-4. Summary of Analysis of Variance of Manufacturing Companies' Financial Performance by CFA methods Adoption.

\begin{tabular}{l|l|l|l|l|l}
\hline & Sum of Squares & df & Mean Square & F & $P$-value \\
\hline Between Groups & 9699.85 & 2 & 4849.93 & 37.14 & .00 \\
\hline Within Groups & 6920.54 & 53 & 130.57 & & \\
\hline Total & 16620.39 & 55 & & & \\
\hline
\end{tabular}

Table 4 above shows that non adopters, partial adopters and full adopters of Competitor Focused Accounting Methods differ significantly in their financial performance, $\mathrm{F}=37.14, \quad P$ value $=.00$ (less than the 0.05 significance level). The null hypothesis therefore, was not supported. It was concluded that the differences in mean financial performance of between the groups was statistically significant. Although this ANOVA result shows that a significant difference exists as suggested by Sizeable F-ratio statistic and P-value less than 0.05, but it does not reveal which of the groups differ from the other since there are three groups. Since these possibilities were unresolved by the ANOVA test, Post-hoc scheffe test is used to determine which of the group's financial performance is significantly less or greater than the other. This is shown in table 4 below.

Table-5. Scheffe's Pair-wise Comparison

\begin{tabular}{l|l|l|l}
\hline $\begin{array}{l}\text { (I) Adoption of competitor } \\
\text { Focused Accounting } \\
\text { Methods }\end{array}$ & $\begin{array}{l}\text { (J) Adoption of competitor } \\
\text { Focused Mccounting } \\
\text { Methods }\end{array}$ & Mean Difference (I-J) & $P$-value \\
\hline Non Adopters & Partial Adopters & $-20.607^{*}$ & .00 \\
\hline \multirow{2}{*}{ Partial Adopters } & Full Adopters & $-45.703^{*}$ & .00 \\
\hline \multirow{2}{*}{ Full Adopters } & Non Adopters & $20.607^{*}$ & .00 \\
\cline { 2 - 4 } & Full Adopters & $-25.097^{*}$ & .00 \\
\hline & Non Adopters & $45.703^{*}$ & .00 \\
\cline { 2 - 4 } & Partial Adopters & $25.097^{*}$ & .00 \\
\hline
\end{tabular}

According to table 5, the following can be deduced: Financial performance of non -adopters were less than that of partial adopters (Mean difference $=-20.607$ ). Similarly, the financial performance of non-adopters was less than the financial performance of full adopters (-45.703). 
When financial performance of partial adopters was compared with that of non-adopters, it was found that partial adopters financial performance was 20.607 greater than that of non-adopters (mean difference $=20.607)$. However, partial adopters were 25.097 less than full adopters in financial performance (mean difference $=-25.097$ ). Full adopters' financial performance was found to be greater than financial performance of both non adopters and partial adopters (Mean differences $=45.703 \& 25.097)$. These mean differences were all statistically different as shown by the P-values $=.00$ which were less than 0.05 significance level. We conclude that full adopters, partial adopters and non adopters of CFA methods differ significantly in financial performance.

\section{CONCLUSION AND RECOMMENDATION}

In formulating business strategy, Management must consider the strategies of the firm's competitors; hence, a firm's strategy is then likely to succeed only if it includes a strategy for "managing" its competitors. In the light of this, the study has enriched our knowledge on the current state of CFA information usage in Nigerian manufacturing sector. However, the study shows that the adoption of CFA in Nigerian companies is below average. The necessity to improve this situation in our current competitive economic condition is a challenge and obligation for our accounting profession. In addition, this study provides important implications for the management of manufacturing organizations. In order to attain competitive advantage and improve financial performance, manufacturing firms need to demonstrate a high level usage of CFA methods.Consequently, the paper recommended that, manufacturing organizations should embrace and apply the methods of CFA as a complete package and avoid partial application. They should set up standards for the application and ensure that success factors like having adequate personnel and developed accounting system are in place.

\section{REFERENCES}

Akenbor, C.O., 2011. Strategic management accounting and competitive advantage in the manufacturing industry: A study of selected manufacturing industrial firms in Nigeria. Unpublished Ph.D. Dissertation, Nnamdi Azikiwe University, Awka.

Akenbor, C.O. and E.I. Okoye, 2011. Competitor accounting and corporate profitability of manufacturing firms in Nigeria. ESUT Journal of Management Sciences, 6(1): 1-13.

Bromwish, M., 1990. The case for strategic management accounting: The role of accounting information for strategy in competitive markets. Accounting, Organization and Society, 15(1): 27-46.

Cadez, S. and C. Guilding, 2008. Strategy and strategic management accounting: An investigation of organization configurations. Research Seminar: Manchester Business School. MBS Seminar. Available from http://research.mbs.ac.uk/2008 [Accessed on 24/11/2012].

Drury, C., 2008. Management and cost accounting. London: Cengage Learning.

Gan, K. and Z. Selah, 2008. Intellectual capital and corporate performance of technology intensive companies: Malaysia evidence. Asia Journal of Business and Accounting, 1(1): 113-130.

Grundy, T., 1997. Management accounting for strategic performance. Management Accounting, December.

Guilding, C., 1999. Competitor-focused accounting: An exploratory note. Accounting, Organizations and Society, 24(7): 583-595. 
Guilding, C., K.S. Cravens and M. Tayles, 2000. An international comparison of strategic management accounting practices. Management Accounting Research, (11): 113-135.

Hassan, N., N. Muhammad and Z. Ismail, 2011. Strategic management accounting practice in Malaysia: Case of manufacturing sector. Journal of Finance, Accounting and Management, 2(2): 23-38.

Heinen, C. and A. Hoffjan, 2005. The strategic relevance of competitor cost assessment: An empirical study of competitor accounting. Journal of Management Accounting Research, 3(1): 17-21.

Hesford, J.W., 2008. An empirical investigation of accounting information use in competitive intelligence. Journal of Competitive Intelligence and Management, 4(3): 17-49.

Johnson, M.B., 2002. Competitive profiling with financial ratio analysis. Competitive Intelligence Magazine, $5(1): 35-39$.

Jones, L., 1988. Competitor cost analysis at caterpillar. Management Accounting October, (70): 32-38.

Lynch, R., 2000. Corporate strategy. 2nd Edn., New York: Prentice Hall.

Malinic, S., D. Jovanovic and S. Jankovic, 2012. Competitive management accounting: Response to the challenges of strategic business decision making. Economics and Organizations, 9(3): 297-309.

Marian, G.C., 2011. The influence of intellectual capital on Romanian companies financial performance. Annales Universitatis Apulensis Series Economica, 2(13): 9.

Moon, P. and K. Bates, 1993. Core analysis in strategic performance appraisal. Management Accounting Research, 4(4): 139-152.

Nigerians Stock Exchange Factbook, 2011/12. Available from http://busnigeria.blogspot.com/2011/12/selection-of-maritime-operators-first.html.

Nzewi, U.C., 2009. An analysis of the profitability of commercial banks in the post consolidated period in Nigeria. Journal of the Management Sciences, 9(2): 179-196.

Porter, M.E., 1980. Competitive strategy: Techniques for analyzing industries and competitors. New York: Free Press.

Richard, P.J., T.M. Devinney, G.S. Yip and G. Johnson, 2009. Measuring organizational performance: Towards methodological best practice. Journal of Mangement. Available from http://jom.sagepub.Com/content/early/2009/02/06/0149206308330560.abstract_ [Accessed $5 / 7 / 11]$.

Rogers, E.M., 1995. Diffusion of innovations. 4th Edn., New York: Free Press.

Sangosanya, A.O., 2011. Firms growth dynamics in Nigeria's manufacturing industry: A panel analysis. Journal of Applied Econometric Review, 1(1): 1-18.

Simmonds, K., 1986. The accounting assessment of competitive position. European Journal of Marketing, 20(1): 16-31.

Subramanian, R. and S.T. IsHak, 1998. Competitor analysis practice of US companies: An empirical investigation. Management International Review, 38(1): 7-23.

Uzoagulu, A.E., 1998. Practical guide to writing research projects in tertiary institutions. Enugu: John Jacobs's Classic Publisher Ltd.

Ward, K., 1996. 2nd Edn., Accounting for marketing strategy. In Drury, C. (Ed). Management accounting handbook. Oxford: Butterworth Heinemann. 